\title{
PENGARUH PENDIDIKAN DAN LATIHAN DALAM MENINGKATKAN KINERJA PEGAWAI PADA DINAS LINGKUNGAN HIDUP KABUPATEN LAMPUNG BARAT
}

\author{
Ledi Kurniawan ${ }^{(1)}$, Husna Purnama ${ }^{(2)}, \operatorname{Kuswarak}^{(3)}$ \\ Fakultas Ekonomi Universitas Sang Bumi Ruwa Jurai \\ ledi_kurniawan001@gmail.com, husna.purnama@fe.saburai.ac.id,kuswarak@fe.saburai.ac.id
}

\begin{abstract}
Abstrak. Program pendidikan dan latihan itu dilaksanakan diharapkan adanya peningkatan kinerja dalam bagian pada suatu organisasi yang dimaksudkan untuk meningkatkan hasil produktivitas kinerja pegawai. Program pendidikan dan latihan bagi pegawai masih dianggap kurang berjalan sesuai dengan harapan, kinerja pegawai yang belum optimal pada Dinas Lingkungan Hidup Kabupaten Lampung Barat. Tujuan dari penelitian ini adalah untuk mengetahui Pengaruh Pendidikan dan latihan dalam meningkatkan kinerja pegawai pada Dinas Lingkungan Hidup Kabupaten Lampung Barat. Metode analisis yang digunakan analisis kualitatif dan kuantitatif. Hipotesis yang diajukan dalam penelitian ini adalah "Pendidikan dan pelatihan berpengaruh positif terhadap Kinerja Pegawai pada Dinas Lingkungan Hidup Kabupaten Lampung Barat". Pengumpulan data penelitian menggunakan teknik populasi penelitian dari 26 responden. Persamaan regresi linier sederhananya adalah $\mathrm{Y}=1,511+1,526(\mathrm{X})$, hasil pengujian menggunakan rumus $\mathrm{t}$ student, menunjukkan bahwa $\mathrm{t}$ hitung $15,951>\mathrm{t}$ tabel 2,059 , berarti ada pengaruh pendidikan dan pelatihan terhadap kinerja pegawai pada Dinas Lingkungan Hidup Kabupaten Lampung Barat.
\end{abstract}

Kata kunci: Latihan, Kinerja, Pendidikan, Pegawai.

\section{PENDAHULUAN}

Rencana Kerja Tahun 2018 Dinas Lingkungan Hidup Kabupaten Lampung Barat nantinya lebih diarahkan pada optimalisasi dan sinergisitas segala potensi yang dimiliki untuk menjawab segala tuntutan kebutuhan pembangunan dibidang pengelolaan dan perlindungan lingkungan hidup. Dalam rangka menunjang hal tersebut Dinas Lingkungan Hidup Kabupaten Lampung Barat Kawasan hutan yang kritis sudah pada tingkat yang mengakhawatirkan Kawasan hutan kritis menyebabkan erosi, banjir, tanah longsor, sedimentasi tinggi, penurunan kualitas air, fluktuasi debit air,juga mengakibatkan hilangnya plasma nutfah berkurangnya keanekaragaman hayati, rusaknya habitat satwa langka yang dilindungi sehingga satwa-satwa tersebut sering mengganggu permukiman penduduk.

Keberhasilan dan kegagalan pembangunan tidak dapat lepas dari peran yang dimainkan oleh aparatur pemerintahan sebagai abdi negara dan abdi masyarakat. Peranan tersebut diwujudkan dalam bentuk kinerja pegawai dalam organisasi yang menjadi penggerak dan menjadi satu kesatuan dalam pola manajemen pemerintahan dan manajemen pembangunan daerah.

Seiring berkembangnya ilmu dan pengetahuan yang makin maju maka instansi/satker dituntut untuk lebih dapat menjadikan pegawainya lebih terampil dan terlatih dalam mengerjakan tugasnya. Oleh karena itu organisasi berinisiatif untuk mengadakan program pendidikan latihan bagi pegawainya, karena pendidikan dan latihan membuat mereka lebih percaya diri sehingga menimbulkan rasa puas dalam bekerja dan lebih dihargai, serta mampu berusaha untuk meningkatkan kinerja pegawai.

Setelah program pendidikan dan latihan itu dilaksanakan diharapkan adanya peningkatan kinerja dalam bagian pada 
suatu organisasi yang dimaksudkan untuk meningkatkan hasil produktivitas kinerja pegawai. Program pendidikan dan latihan dianggap membawa manfaat yang cukup besar bagi organisasi seperti meningkatkan moral pegawai, meningkatkan efisiensi waktu dalam melaksanakan pekerjaannya.

Untuk mencapai tujuan yang dimaksud sudah barang tentu memerlukan keterlibatan Sumber Daya Manusia (SDM) dalam organisasi tersebut, khususnya kemampuan administratif pegawai karena hal tersebut akan mempengaruhi efektivitas suatu organisasi. Pekerjaan yang berlainan dan ditangani oleh orang yang pendidikannya sesuai dan terampil dalam bidangnya akan mempengaruhi cara pandang, tujuan, kebutuhan, dan kemampuan yang berbeda dalam pencapaian tujuan organisasi berdasarkan visi dan misi organisasi.

Dengan kualitas kinerja pegawai yang semakin meningkat diharapkan adanya perubahan kerja. Kinerja pegawai yang meningkat akan menimbulkan rasa memiliki organisasi dan akan tercipta rasa kepuasan, baik pada individu maupun organisasi secara keseluruhan. Elemen yang digunakan dalam analisa ini adalah kondisi pegawai menurut jenjang pendidikan formal dan keadaan pegawai berdasarkan jenjang pendidikan karier.

Berdasarkan fenomena di atas, maka peneliti bermaksud melakukan penelitian mengenai pendidikan dan latihan terhadap kinerja yang berjudul: "Pengaruh Pendidikan dan Latihan dalam Meningkatkan Kinerja Pegawai pada Dinas Lingkungan Hidup Kabupaten Lampung Barat".

\section{KAJIAN TEORI}

\section{Pengertian Pendidikan dan latihan}

Menurut Mangkunegara, A.A. Anwar Prabu, Pendidikan dan latihan adalah setiap usaha untuk memperbaiki performan pekerja pada suatu pekerjaan tertentu yang sedang menjadi tanggungjawabnya, atau suatu pekerjaan yang ada kaitannya dengan pekerjaannya (Mangkunegara, 2008), Supaya efektif, pelatihan biasanya harus mencakup pengalaman belajar (learning experience), aktivitas-aktivitas yang terencana (be a planned organizational activity), dan didesain sebagai jawaban atas kebutuhankebutuhan yang berhasil diidentifikasikan. Secara ideal, pelatihan harus didesain untuk meunjukkan tujuan-tujuan organisasi yang pada waktu bersamaan juga menunjukkan tujuan-tujuan dari para pekerja secara perorangan.

Istilah pendidikan dan latihan sering disamakan dengan istilah pengembangan. Pengembangan (development) menunjuk pada kesempatan-kesempatan belajar (learning opportunities) yang didesain guna membantu pengembangan para pekerja. Kesempatan yang demikan tidak terbatas pada upaya perbaikan performansi pekerja pada pekerjaanya yang sekarang. Jadi pendidikan dan pelatihan langsung berkaitan dengan performansi kerja, sedangkan pengembangan (development) tidak mesti berkaitan. Pengembangan mempunyai skope yang lebih luas dibandingkan dengan pendidikan dan latihan.

Pendidikan dan latihan sering dianggap sebagai aktivitas yang paling dapat dilihat dan paling umum dari semua aktivitas kepegawaian. Para pimpinan organisasi/satker menyokong pendidikan dan latihan karena melalui pendidikan dan latihan para pegawai akan menjadi lebih terampil dan karenanya lebih produktif sekalipun manfaat-manpaat tersebut dapat diperhitungkan dengan waktu yang tersisa ketika para pegawai sedang dididik dan dilatih.

Para pegawai menyukai pendidikan dan latihan karena pendidikan dan latihan 
membebaskan dari pekerjaan mereka (jika mereka tidak suka pada pekerjaannya) atau meningkatkan kecakapan yang bisa digunakan untuk menguasai kedudukan yang sedang mereka duduki atau yang akan mereka duduki. Pendidikan dan latihan juga sering dianggap sebagai imbalan dari organisasi dan suatu simbol status, atau suatu liburan dari kewajiban-kewajiban kerja sehari hari.

Menurut Mangkunegara, A.A. Anwar Prabu, pendidikan dan latihan hanya bermanfaat dalam situasi dimana para pegawai kekurangan kecakapan dan pengetahuan. Pendidikan dan latihan tidak di maksudkan untuk menggantikan kriteria seleksi yang tidak memadai, ketidaktepatan rancangan pekerjaan, atau imbalan organisasi yang tidak memadai.

Pelatihan lebih sebagai sarana yang ditujukan pada upaya yang lebih mengaktifkan kerja para anggota organisasi yang kurang aktif sebelumnya, dan mengurangi dampak-dampak negatif yang dikarenakan kurangnya pendidikan, pengalaman yang terbatas, atau kurangnya kepercayaan diri dari anggota atau kelompok anggota tertentu.

\section{Prinsip Umum bagi Metode Pendidikan dan latihan}

Terlepas dari berbagai metode yang ada, apapun bentuk metode yang dipilih, metode tersebut harus memenuhi prinsip-prinsip seperti:

1. Memotivasi para peserta pelatihan untuk belajar keterampilan yang baru.

2. Memperlihatkan keterampilanketerampilan yang diinginkan untuk dipelajari.

3. Harus konsisten dengan isi (misalnya, menggunakan pendekatan interaktip untuk mengajarkan ketermpilanketerampilan interpersonal).

4. Memungkinkan partisipasi aktif.
5. Memberikan kesempatan berpraktek dan perluasan keterampilan.

6. Memberikan feedback mengenai performansi selama pelatihan.

7. Mendorong adanya pemindahan yang positif dari adanya pelatihan pekerjaan

8. Harus efektif dari segi biaya.

\section{Pengertian Kinerja}

Menurut (Maryoto, 2010) Kinerja pegawai adalah hasil kerja selama periode tertentu dibandingkan dengan berbagai kemungkinan, misal standar, target/sasaran atau kriteria yang telah disepakati bersama, kinerja adalah hasil yang diinginkan dari perilaku. Kinerja individu merupakan dasar dari kinerja organisasi.

Penilaian kinerja ini (performance appraisal) pada dasarnya merupakan faktor kunci guna mengembangkan suatu organisasi secara efektif dan efisien. Pegawai menginginkan dan memerlukan balikan berkenaan dengan prestasi mereka dan penilaian menyediakan kesempatan untuk memberikan balikan kepada mereka jika kinerja tidak sesuai dengan standar, maka penilaian memberikan kesempatan untuk meninjau kemajuan pegawai dan untuk menyusun rencana peningkatan kinerja (Dessler, 2008).

Pengertian kinerja disebut juga sebagai kinerja atau dalam bahasa Inggris disebut dengan performance. Pada prinsipnya, ada istilah lain ang lebih menggambarkan pada "prestasi" dalam bahasa Inggris yaitu kata "achievement". Tetapi karena kata tersebut berasal dari kata "to achieve" yang berarti "mencapai", maka dalam bahasa Indonesia sering diartikan menjadi "pencapaian" atau “apa yang dicapai” (Ruky, 2011).

\section{Penilaian Kinerja}

Penilaian kinerja adalah proses melalui mana organisasi-organisasi mengevaluasi atau menilai kinerja pegawai. Kegiatan ini 
dapat memperbaiki keputusan-keputusan personalia dan memberikan umpan balik kepada para pegawai tentang pelaksanaan kerja mereka (Handoko, 2010).

Kinerja pegawai dibawah standar mungkin disebabkan sejumlah faktor, mulai dari keterampilan kerja yang buruk sehingga motivasi yang tidak cukup atau suasana kerja yang buruk. Dalam kasus seorang pegawai yang memiliki sikap jelek serta tingkat keterampilan rendah, masalah utama mungkin dalam proses seleksi dan biaya yang besar untuk memperbaiki keterampilan maupun sikap sehingga pegawai tersebut lebih baik dipindahkan atau diberhentikan. Seorang pegawai yang mempunyai tingkat keterampilan rendah tetapi memiliki sikap yang baik mungkin membutuhkan pelatihan.

kinerja adalah hasil kerja yang dicapai seseorang baik berupa produk atau jasa dan dalam pelaksanaan tugas atau pekerjaannya sesuai dengan beban tugas yang harus dilaksanakan dengan disertai adanya standart kerja yang telah ditentukan. Prestasi kerja yang baik merupakan langkah awal untuk menuju tercapainya tujuan organisasi. Oleh karena itu perlu diupayakan untuk meningkatkan kinerja pegawai, meskipun hal tersebut tidaklah mudah karena banyaknya faktor yang mempengaruhi, salah satunya adalah penilaian kinerja itu sendiri.

\section{METODE PENELITIAN}

\section{Objek Penelitian}

Objek penelitian ini adalah pegawai di Dinas Lingkungan Hidup Kabupaten Lampung Barat, yang beralamat di Jln. Tulip No.2 Way Mengaku Kecamatan Balik Bukit Kabupaten Lampung Barat. Penelitian ini di laksanakan dari bulan April sampai dengan Juli 2018.

\section{Metode Penelitian}

Penelitian yang akan dilaksanakan adalah jenis penelitian deskriptif kuantitatif. Jenis penelitian ini adalah penelitian yang bermaksud membuat pemaparan secara sistimatis, faktual, dan akurat mengenai fakta - fakta dan sifat - sifat populasi tertentu. Jenis penelitian yang digunakan dalam penelitian ini adalah penelitian lapangan (field reseach), bersifat kuantitatif dimana penjelasannya bersifat objektif dengan menjelaskan pendekatanpendekatan yang ada.

\section{Metode dan Teknik Pengumpulan Data}

Dalam penelitian ini jenis data yang diperlukan adalah:

\section{a. Data Primer \\ Pengumpulan data primer dilakukan} melalui survey ke lapangan secara langsung yang disertai dengan wawancara secara terbuka yang dilakukan dengan pegawai Dinas Dinas Lingkungan Hidup Kabupaten Lampung Barat.

\section{b. Data Sekunder}

Mencatat data-data yang dipublikasikan Kantor Dinas Lingkungan Hidup Kabupaten Lampung Barat dalam bentuk aplikasi dilapangan yang sifatnya berkala (time series). Untuk mendapatkan dan mengumpulkan data yang sesuai dengan kebutuhan dalam penelitian ini maka teknik-teknik yang digunakan adalah sebagai berikut:

\section{Observasi}

yaitu pengamatan langsung guna menguji kebenaran hasil wawancara yang telah dilakukan sebelumnya hingga diperoleh bukti dan fakta empiris dari kantor tersebut. 
2. Wawancara

dilakukan dengan cara bertemu langsung dan bertanya secara langsung dengan pegawai Kantor Dinas Lingkungan Hidup Kabupaten Lampung Barat.

\section{Kuisioner}

yaitu melakukan penyebaran daftar pernyataan yang diajukan kepada pegawai Kantor Dinas Lingkungan Hidup Kabupaten Lampung Barat.

\section{Telaah Dokumentasi dan Kepustakaan}

yaitu suatu teknik pengumpulan data yang dilakukan peneliti dengan cara mengkaji buku-buku bacaan, dokumendokumen, peraturan-peraturan dan ketentuan undang-undang serta kebijaksanaan-kebijaksanaan yang berkaitan dengan pokok permasalahan.

\section{Sampel dan Populasi}

Sampel penelitian adalah sebagian dari populasi yang mewakili sifat dan karakter yang sama. Dengan mengambil sampel dimaksudkan untuk menyederhanakan jumlah subjek yang harus diteliti, tetapi hasil penelitian terhadap sampel itu akan digeneralisasikan pada populasi yang ada. Untuk menentukan banyak sampel, peneliti menggunakan pedoman dari pendapat Arikunto Suharsimi (2010).

Apabila subyeknya kurang dari 100, lebih baik diambil semua sehingga penelitiannya merupakan penelitian populasi. Selanjutnya jika jumlah subyeknya besar, dapat diambil 10\% - 15\% atau $20 \%-25 \%$ atau lebih. Dalam penelitian ini merupakan penelitian sampel dengan menggunakan teknik sensus. Adapun jumlah sampel yang diperoleh adalah seluruh populasi pegawai Dinas Lingkungan Hidup Kabupaten Lampung Barat yang berjumlah 26 orang pegawai.

\section{Analisis Kualitatif dan Kuantitatif}

Analisa kualitatif digunakan sebagai metode untuk menganalisa permasalahan berdasarkan konsep dan teori manajemen sumber daya manusia. Dalam metode ini juga menganalisa masalah dengan teoriteori yang berkaitan dengan masalah kepemimpinan dan kinerja. Analisis kualitatif dilakukan dengan analisis tabel tunggal atau secara parsial yang menggambarkan kriteria masing-masing variabel independent dan variabel dependent. Termasuk kedalam kriteria mana masing-masing variabel penelitian tersebut sesuai dengan jawaban yang ada pada pengukuran variabel diatas.

Analisis kuantitatif yang dilakukan berdasarkan data primer yang diperoleh dari penyebaran instrument (daftar pertanyaan) kepada sampel, dan untuk mengetahui pengaruh dari variabel bebas (independent variable) terhadap variabel terikat (dependent variable).

Rumus yang digunakan untuk mengukur sejauh mana pengaruh kepemimpinan terhadap kinerja pegawai Kantor Dinas Lingkungan Hidup Kabupaten Lampung Barat dengan persamaan regresi linear berganda dengan rumus sebagai berikut :

Persamaan Regresi Linear Sederhana menentukan persamaan regresi linear sederhana untuk X :

$$
Y=a+b X+e
$$

Keterangan:

$\mathrm{Y}=$ Kinerja Pegawai

$\mathrm{a}=$ Konstanta

$\mathrm{b}=$ Koefisien regresi $\mathrm{X}$

$\mathrm{X}=$ Pendidikan dan Pelatihan

$\mathrm{e}=$ Faktor kesalahan 
Scoring yaitu mengubah data yang bersifat kualitatif kedalam bentuk kuantitatif (skor nilai). Dalam penentuan skor nilai ini digunakan skala likert dengan lima kategori penilaian yang ditunjukkan oleh Tabel 1.

Tabel 1. Skala Likert pada pertanyaan-pertanyaan tertutup dalam kuesioner

\begin{tabular}{lc}
\hline \multicolumn{1}{c}{ Pilihan Jawaban } & Skor \\
\hline Sangat setuju & 5 \\
Setuju & 4 \\
Kurang setuju & 3 \\
Tidak setuju & 2 \\
Sangat tidak setuju & 1 \\
\hline
\end{tabular}

Penggunaan skala likert dengan alternatif skor nilai $1-5$ untuk mengukur sikap, dan pendapat responden. Pendapat yang paling positif diberi skoe 5 (maksimum), dan pendapat yang paling negatif diberi angka 1 (minimum). Dengan pertimbangan agar responden lebih mudah dalam menentukan pilihan jawaban, karena peneliti meyakini bahwa responden telah familiar dengan angka tersebut.

Untuk mengetahui besarnya pengaruh, penghitungan koefisien korelasi tersebut kemudian dilanjutkan dengan Rumus Koefisien Determinasi atau Koefisien Penentu (KP):

$$
K P=(r)^{2} x 100 \%
$$

Untuk menguji hipotesis secara parsial digunakan Uji t dengan rumus :

$$
t_{\text {hitung }}=\frac{r \sqrt{N-2}}{\sqrt{1-r^{2}}}
$$

Keterangan:

$$
\begin{array}{ll}
\mathrm{t}_{\text {hitung }} & =\text { Nilai } \mathrm{t} \\
\mathrm{r} & =\text { Koefisien Korelasi } \\
\mathrm{N} & =\text { Jumlah responden }
\end{array}
$$

(Sugiyono, 2008).
Kriteria untuk Uji $\mathrm{t}$ adalah sebagai berikut :

a) Jika $t_{\text {hitung }}>t_{\text {tabel }}$ maka Ha diterima dan Ho ditolak.

b) Jika $t_{\text {hitung }} \leq \mathrm{t}_{\text {tabel }}$ maka Ha ditolak dan Ho diterima.

\section{HASIL DAN PEMBAHASAN}

\section{Uji Validitas dan Uji Reliabilitas Data}

Nilai $r$ hitung pendidikan dan pelatihan lebih besar dari $\mathrm{r}$ tabel (0.514), sehingga seluruh indikator dinyatakan valid. Hasil perhitungan menunjukkan bahwa seluruh indikator untuk variabel kinerja adalah lebih besar dari $\mathrm{r}$ tabel, sehingga seluruh indikator dinyatakan valid.

Uji reliabilitas instrumen menggunakan rumus Cronbach Alpha $(\alpha)$ untuk masing-masing variabel adalah lebih besar dari 0,60. Nilai reliabilitas konsistensi internal menunjukkan koefisien Alpha Cronbach dinyatakan reliable karena lebih besar dari 0,60. Dengan demikian item pengukuran pada masing-masing indicator dalam variabel-variabel penelitian dinyatakan reliable dan selanjutnya dapat digunakan dalam penelitan.

\section{Analisis Kuantitatif}

Dari pengolahan data statistik maka diperoleh persamaan regresi linier sederhana $\mathrm{Y}=1,511+1,526(\mathrm{X})$. Nilai konstanta yang diperoleh sebesar 1,511, hal ini berarti bahwa jika variabel independen (pendidikan dan latihan) adalah bernilai nol, maka besarnyakinerja yang terjadi adalah 1,511. Nilai koefisien regresi variabel pendidikan dan latihan $(\mathrm{X})$ sebesar 1,526, hal ini menunjukkan bahwa setiap kenaikan satu satuan pendidikan dan latihan akan mengakibatkan kenaikan kinerja sebesar 1,526. 
Koefisien determinan

$\left(\mathrm{R}^{2}\right)$

digunakan untuk mengetahui kontribusi variabel bebas dalam menjelaskan variabel terikat. Semakin besar nilai koefisien determinasimaka menunjukkan semakin besar pula pengaruh variabel terikat terhadap variabel bebas. Hasil pengujian menunjukkan bahwa nilai $R$ square sebesar 0,914 . Nilai $R$ square ini menunjukkan bahwa besarnya kontribusi variabel independen terhadap variabel dependen adalah sebesar $91,4 \%$, sedangkan sisanya sebesar 8,6\% ditentukan oleh variabel lain yang tidak teridentifikasi dalam penelitian ini.

Pengujian model kelayakan hipotesis penelitian dilakukan dengan menggunakan uji t pada tingkat kepercayaan $95 \%$ atau $\alpha$ sebesar 0.05 , apabila $t_{\text {hitung }}>t_{\text {tabel. }}$ maka model dinyatakan layak digunakan dalam penelitian ini dan sebaliknya apabila $t_{\text {hitung }}<t_{\text {tabel, }}$ maka model dikatakan tidak layak, atau dengan signifikan $(\mathrm{Sig})<0.05$ maka model dinyatakan layak digunakan dalam penelitian ini dan sebaliknya apabila signifikan (Sig) > 0.05 maka model dinyatakan tidak layak digunakan.

Pengujian dapat menjawab hipotesis yang menyatakan "pendidikan dan latihan terhadap kinerja". Pengujian dilakukan dengan menggunakan uji $\mathrm{t}$ yang menunjukkan bahwa pendidikan dan latihan berpengaruh terhadap kinerja. Pengujian dilakukan dengan menggunakan uji t pada tingkat keyakinan signifikansi $\alpha 0.05$. Dari hasil dapat diketahui bahwa tingkat signifikansi sebesar $0.00<0.05$ dengan nilai $t_{\text {hitung }}>t_{\text {tabel }}$ yaitu $15,951>2,059$. Dengan demikian hipotesis diterima yang berarti pendidikan dan latihan berpengaruh terhadap kinerja.

\section{KESIMPULAN DAN SARAN}

\section{Kesimpulan}

Berdasarkan hasil penelitian disimpulkan bahwa pengujian hipotesis yang menyatakan "pendidikan dan latihan berpengaruh terhadap kinerja". Pengujian dilakukan dengan menggunakan uji t pada tingkat keyakinan signifikansi $\alpha 0,05$. Nilai $R$ square sebesar 0,914 ini menunjukkan bahwa besarnya kontribusi variabel independen terhadap variabel dependen adalah sebesar $91,4 \%$, sedangkan sisanya sebesar 8,6\% ditentukan oleh variabel lain yang tidak teridentifikasi dalam penelitian ini. Nilai signifikansi sebesar 0,001 lebih kecil dari 0,05. Dari hasil yang diperoleh dapat diketahui bahwa tingkat signifikansi sebesar $0,001<0,05$ dengan nilai $t_{\text {hitung }}>$ $t_{\text {tabel }}$ yaitu 15,951>2,059, dengan demikian hipotesis diterima yang berarti pendidikan dan latihan berpengaruh terhadap kinerja.

\section{Saran}

Adapun saran yang diajukan peneliti adalah sebagai berikut:

1. Dinas Lingkungan Hidup Kabupaten Lampung Barat hendaknya memberi kesempatan bagi pegawainya untuk mengikuti pendidikan dan latihan secara berkelanjutan dan terstruktur yang diberikan agar pegawai semakin termotivasi untuk meningkatkan kinerjanya.

2. Dinas Lingkungan Hidup Kabupaten Lampung Barat hendaknya memberikan tambahan pendidikan dan latihan sesuai dengan jenjang pendidikan masingmasing pegawai.

3. Dinas Lingkungan Hidup Kabupaten Lampung Barat hendaknya memberikan rewand kepada pegawai yang berhasil dalam menempuh pendidikan dan latihan. 


\section{DAFTAR PUSTAKA}

Alex, Eka Jaya. 2011. "Pengaruh Peningkatan

Pendidikan dan latihan (Diklat) Terhadap Kinerja Pegawai Pada Dinas Perhubungan Kabupaten Tanggamus.

Budiyono. 2009. Metode Kuantitatif Penelitian. Jakarta: ANDI Offset.

Blanchard dan Spencer. 2009.Management. Jakarta: BP FE UI.

Dwiyanto. 2010. Manajemen Sumber Daya Manusia, Jilid I. Jakarta: PT. Indeks.

Handoko, T. Hani. 2010. Manajemen Sumber Daya Manusia Strategi. Jakarta : Ghalia Indonesia.

Mangkunegara, A.A Anwar Prabu. 2008. Perencanaan dan Pengembangan SDM. Bandung: Refika Aditama.

Maryoto. 2010. Manajemen Sumber Daya Manusia, edisi ke enam. Jakarta: Erlangga.

Purnamasari. 2008. Program SPSS Penelitian Bisinis. Jakarta: Erlangga.

Rahmanto. 2010. Manajemen SDM. Edisi Revisi, Cetakan Ke Tujuh. Jakarta: Bumi Aksara.

Ruky. 2011. Manajemen Sumber Daya Manusia Strategi. Jakarta: Ghalia Indonesia.

Safrudin. 2014. Analisis Pelaksanaan Pendidikan dan Pelatihan Dalam Upaya Peningkatan Kinerja Pegawai Negeri Sipil Di Dinas Kelautan Dan Perikanan Pemerintah Kabupaten Lampung Barat.
Suharsimi, Arikunto. 2010. Metode Penelitian. Jakarta: BP FE UI.

Sugiyono. 2008. Cetakan kelima, Statistika Untuk Penelitian. Bandung: Alfabetta.

Sundari. 2016. Pengaruh Pendidikan dan Pelatihan Terhadap Kinerja Pada Sekolah Polisi Negara (SPN) Polda Lampung.

Tjandinegara, Elvira. 2012. Pengaruh Pendidikan dan latihan terhadap Kinerja Pegawai pada Dinas Perhubungan Kabupaten Lampung Tengah. 